\title{
ANALISIS KEUNTUNGAN PRODUSEN BABI PUTAR DI KECAMATAN TUMINTING KOTA MANADO (Studi Kasus Usaha Babi Putar Simponi)
}

\author{
Febrion Gura, S. P. Pangemanan*, J. K. J. Kalangi, I. D. R. Lumenta
}

Fakultas Peternakan Universitas Sam Ratulangi Manado, 95115

\begin{abstract}
ABSTRAK
Penelitian ini bertujuan untuk mengetahui gambaran usaha babi putar, pengolahan babi putar dan keuntungan yang dihasilkan. Penelitian ini dilaksanakan di Kecamatan Tuminting Kota Manado pada tanggal 1 Februari 2019 sampai tanggal 28 Februari 2019, Penelitian ini menggunakan metode study kasus pada usaha babi putar Simponi. Pengumpulan data dilakukan dengan metode survey dengan menggunakan kuesioner dan dianalisis secara deskriptif untuk menggambarkan usaha babi putar Simponi. Hasil penelitian menunjukan bahwa karakteristik responden pengusaha babi putar Simponi masuk dalam usia produktif, Mempunyai pendidikan SMA, mempunyai pengalaman usaha selama 12 tahun. Proses pembuatan babi putar diawali dengan penyembelihan, membersikan bulu dan kulit epidermis, pengeluaran organ dalam atau jeroan, babi ditusuk dengan alat pemutar dan mengikat mulut dan keempat kaki, olesi secara merata semua bagian tubuh babi dengan bumbu yang disediakan. Setelah itu angkat ketempat pemutar sambil memutar alat pemutar. Warna kulit babi yang dari putih menjadi coklat kemerahan nampak empuk dan kulitnya sudah guri (tore) babi putar sudah matang. Babi kemudian diangkat untuk masuka pada proses pengemasan. Analisi keuntungan usaha babi putar Simponi mempunyai total
\end{abstract}

Korespondensi (corresponding author)

Email: stevypangemanan@unsrat.ac.id
Keuntungan yang didapatkan Rp. 154.356.553/tahun.

Kata Kunci : Analisis Keuntungan, Babi Putar

\begin{tabular}{|c|c|c|}
\hline \multicolumn{3}{|c|}{ ABSTRACT } \\
\hline PROFIT & ANALYSIS & OF PRODUCE \\
\hline FOR & ROASTED & PORK \\
\hline
\end{tabular}

(Case Study at Simponi Roasted Roll

Pork Business). Study was done to evaluate profit of roasted Roll Pork business in Tuminting district of Manado. Study was conducted on February 1 to 28, 2019. Data were collected based on case study with survey method. Data were analyzed by descriptive method to describe the profit of Simponi roasted roll pork trade. Results showed that owner characteristic of Simponi roasted roll pork trade was categorized into productive age with education level of high school and the experience of 12 years on roasted roll pork trade. Processing of roasted roll pork was initiated of slaughtering and dressing carcass of entrails with the whole intact body condition. The whole carcass body condition was sticked using roll sticker from mouth to the anus part of animal. Parts of mouth and four legs were tied into sticker. The whole animal body and stomach area were lubricated with cooking spices. These entire spicy lubricated carcasses under sticker were roasted above warmer fire done under rolling sticker. The white skin color was gradually changing into redbrownish color and soft tender skin 
indicating well done roasted roll pork. The well done roasted roll pork was wraped and ready to be served on dish of food offered to the consumers. The total cost spent providing roasted roll pork at Simponi were IDR 353.843.447 per year.-. The total revenue were IDR 508.200.000 per year.-. Therefore, the profits were IDR 154.356.553 per year.

Key Word: Profit analysis, roasted roll pork.

\section{PENDAHULUAN}

Indonesia sebagai negara agraris dengan potensi pertanian, peternakan dan perikanan yang cukup besar, menjadi salah satu ujung tombak pembangunan ekonomi nasional, dimana sebagian besar penduduk di Indonesia menggantungkan hidupnya dari sektor pertanian. Salah satu potensi sektor pertanian yaitu sub sector peternakan berguna untuk memenuhi kebutuhan protein hewani berupa daging, telur dan susu. Ternak babi merupakan salah satu komoditas sub sektor peternakan yang dikembangkan untuk menghasilkan daging nasional. Beberapa daerah di Indonesia seperti Propinsi Bali, Kalimantan Barat, Nusa Tenggara Timur, Sulawesi Utara dan Kalimantan barat, pemeliharaan ternak Babi dilakukankan secara professional. Menurut BPS Sulut (2018), bahwa produksi daging babi di Sulawesi Utara tahun 2018 menduduki peringkat keempat setelah Propinsi Bali, Sumatra Utara dan Nusa
Tenggara Timur dengan jumlah produksi 25.194 ton, hal ini karena jumlah populasi masyarakatnya yang beragama Kristen dan agama lain cukup besar (masyarakat yang menganut agama Kristen tidak dilarang mengkonsumsi daging babi (Kandou, 2009), sehingga produksi daging babi cukup tinggi di daerah-daerah ini BPS Sulut (2018)

Produk daging babi sebagai salah satu pemenuhan protein hewani masyarakat, pada beberapa tempat di Indonesia diolah sebagai produk atau makanan khas/tradisional seperti babi guling di Bali (Sastrawan et al., 2017), babi garo, babi tore, Loba (Rawis et al., 2016), atau dipakai di upacara adat atau agama (Suarna et al., 2015). Menurut Juliandri et al. (2017) dan Ernayati (2003) menjelaskan tentang makanan tradisional bahwa istilah tradisional memiliki makna sebagai sesuatu yang sifatnya turun temurun dan menurut adat suatu daerah, sedangkan makanan memiliki arti sesuatu yang dimasukan melalui mulut yang berfungsi memberi nutrisi kepada tubuh. Salah satu makanan khas yang berkembang di Kota Manado dari produk ternak babi adalah babi putar. Babi putar merupakan kuliner khas Minahasa (Manado) yang disediakan dalam pestapesta, syukur seperti perkawinan, ulang tahun dan lainnya. Bagi masyarakat Kota 
Manado babi putar mempunyai rasa yang khas dan nikmat, babi putar disajikan bersama dabu-dabu atau sambal. Bagi keluarga yang menyediakan merupakan suatu prestise acara yang dibuat atau mempunyai makna kualitas makanan yang mahal dan bergengsi. Perkembangan makanan khas Babi putar di Kota Manado sudah cukup lama disediakan oleh usahausaha kecil pesanan Babi putar di sekitar pasar tuminting, pasar 45, Kota Tomohon dan lainnya.

Dua misi utama dalam meningkatkan pengembangan ekonomi Kota Manado berdasarkan RPJMD (2010-2015) yaitu membangun identitas dan citra kota sebagai model ekowisata dunia dan meningkatkan pengembangan ekonomi kawasan lewat dibukanya berbagai jenis usaha makanan dan minuman yaitu restoran, kafe, pabrik kue, pabrik minuman, katering dan industri rumah tangga makanan tradisional/ringan yang termasuk UMKM (Usaha Mikro, Kecil dan Menengah). Pengembangan wisata kuliner perlu informasi mendalam terutama terhadap usaha mikro dan usaha kecil (Pitanatri, 2016). Usaha pesanan babi putar banyak dilakukan oleh usaha kecil yang walaupun sudah memiliki pengalaman usaha yang cukup namun masih terbatas dalam meningkatkan usahanya. Menurut Hapsari
(2014) usaha kecil menengah bergerak dalam kondisi yang amat kompetitif dan ketidakpastian juga sangat dipengaruhi oleh situasi ekonomi makro, (Hartono dan Deny Dwi Hartono, 2014) masalah finansial pada usaha kecil diantaranya prosedur kredit yang cukup rumit, bunga kredit untuk modal kerja yang cukup tinggi dan banyak UKM yang tidak mempunyai kemampuan manejemen keuangan (menejerial dan finansial) sehingga tidak dipercaya oleh pihak pemberi pinjaman dan tidak memiliki ijin usaha.

Beberapa usaha pesanan babi putar telah menjalankan usahanya di Kota Manado selama bertahun-tahun. Tetapi informasi ilmiah dari usaha ini belum ada, untuk itu perlu dilakukan kajian ilmiah yang lebih mendalam yang nantinya digunakan dalam rangka pengembangan makanan khas daerah, mengembangkan tujuan wisata kuliner di Kota Manado dan pengembangan usaha kecil khususnya usaha kuliner pesanan babi putar.

Babi putar Simponi merupakan salah satu usaha pengolahan khusunya babi putar yang berada di Kecamatan Tuminting. Usaha ini mulai dibuka pada tahun 2008 dan berkembang maju dapat dilihat dari penerimaan dan menambah fasilitas pendukung usahannya. Babi putar Simponi juga mengalami persaingan dalam usahanya 
karena di Kota Manado terdapat banyak sekali tempat pengolahan babi putar. Rasa babi putar yang enak dan gurih (tore) juga mempunyai racikan bumbu yang beda dari usaha babi putar lainnya sehingga banyak konsumen yang suka dengan babi putar Simponi karena rasa dan tekstur daging yang khas. Untuk mengetahuai kondisi usaha maka perlu dilakukan pengkajian ekonomi lebih mendalam dalam hal profil usaha, pemasaran dan pendapatan guna meningkatkan usaha ini dan meningkatkan usaha kuliner di Kota Manado khususnya usaha babi putar.

\section{METODE PENELITIAN}

Penelitian ini dilaksanakan di Kecamatan Tuminting Kota Manado pada tanggal 1 Februari 2019 sampai tanggal 28 Februari 2019 pada usaha babi putar Simponi. Metode penelitian yang digunakan adalah metode studi kasus. Pengumpulan data dilakukan dengan metode survey (pengamatan langsung di lapangan untuk mendapatkan keterangan secara terinci mengenai suata daerah tertentu) dan interview atau wawancara secara mendalam dengan menggunakan kuesioner kepada pemilik usaha babi putar Simponi. Data yang dikumpulkan berupa data primer dan data sekunder. Metode analisis data yang digunakan adalah analisis deskriptif untuk menggambarkan kondisi usaha babi putar Simponi, penerimaan dan keuntungan. Menurut Soekartawi (2016), untuk menganalisis biaya produksi, penerimaan dan keuntungan menggunakan rumus:

Keterangan :

$$
\mathrm{TC}=\mathrm{FC}+\mathrm{VC}
$$

$\mathrm{TC}=$ Total Cost

$\mathrm{FC}=$ Fixed Cost (Biaya tetap)

$\mathrm{VC}=$ Variable Cost $($ Biaya variabel $)$

Keterangan :

$$
\mathbf{T R}=\mathbf{P} \cdot \mathbf{Q}
$$

$\mathrm{P}=$ Price $/$ harga

$\mathrm{Q}=$ Quantity / Jumlah barang

Keuntungan adalah selisih antara penerimaan (TR) dengan total biaya (TC)

$$
\boldsymbol{\pi}=\mathbf{T R}-\mathbf{T C}
$$

Keterangan :

$\pi=$ Profit (keuntungan)

$\mathrm{TR}=$ Total Revenue (Total Penerimaan)

$\mathrm{TC}=$ Total Cost $($ Total Biaya $)$

\section{HASIL DAN PEMBAHASAN}

Berdasarkan Tabel 1 bahwa pendidikan dari pemilik usaha babi putar adalah Sekolah Menengah Atas. Taraf pendidikan tingkat menengah atas dapat dijelaskan sudah dapat mempengaruhi pola pikir, ketrampilan dalam bekerja khususnya dalam mengelola usaha pesanan babi putar. Hasil penelitian dari Agustiyarini (2017) menyatakan bahwa tingkat pendidikan seluruh pemilik usaha warung makan yang ada di Kelurahan kampong baru berada pada tingkat pendidikan SMA/SMK. 
Tabel 1. Profil Pengusaha Babi Putar

\begin{tabular}{ccc}
\hline No & Variabel & Keterangan \\
\hline 1. & Pendidikan & SMA \\
2. & Umur & 46 Tahun \\
3. & Lama Usaha & 12 Tahun
\end{tabular}

Hal ini menunjukan bahwa hingga dapat berjalan dengan stabil
pendidikan tingkat menengah atas dominan memiliki kemampuan pengambilan pengusaha jasa makanan karena dianggap telah memiliki kemampuan khususnya dalam mengelola produk dan berwirausaha sehingga dapat bertahan menjalankan usahanya. Faktor umur sangat mempengaruhi produktifitas kerja. Menurut BPS Sulut (2019) bahwa tingkat umur produktif 15 sampai 64 tahun, sehingga umur seseorang sangat mempengaruhi dalam hal ketrampilan dan pengalaman serta penyerapan teknologi baru. Dari hasil wawancara yang dilakukan pemilik usaha memiliki umur yaitu 46 tahun. Kategori umur pemilik usaha masuk dalam usiaproduktif dimana kondisi fisik dan kemampuannya dalam kerja dapat dikatakan produktif.

Pengalaman berwirausaha dimiliki oleh pemilik adalah 12 tahun. Hal ini menunjukan bahwa responden pengusaha mempunyai pengamalaman dalam menjalankan usaha selain itu telah memilikik pengalaman bekerja pada usaha babi putar selama 29 tahun. Penelitian yang dilakukan oleh Baron (2009) ditemukan bahwa pelaku usaha yang sudah merasakan berbagai pengalaman sejak memulai usaha keputusan, memproses informasi dan kemampuan lainya yang lebih baik dibandingkan dengan yang baru memulai usahanya. Hal ini dapat menjelaskan semakin banyak pengalaman dan proses yang dihadapi maka individu tersebut lebih mempunyai kemampuan dalam bertahan dan mencari jalan keluar serta mempunyai kemampuan berinovasi kearah yang lebih baik dalam mengembangkan usaha.

\section{Pengolahan Babi Putar}

Proses pembuatan babi putar dimulai dari pemilihan babi yang akan diolah menjadi babi putar yaitu sesuai ukuran yang dipesan. Pada tahap ini pengusaha akan memesan ternak pada peternak dan dikumpul dalam kandang penampungan. Selanjutnya ternak babi yang dipilih sesuai ukuran dilakukan proses penyembelihan secara tradisional, yaitu ternak babi ditusuk (sticking) menggunakan pisau yang tajam dan panjang kemudian ditusuk tepat dibagian pangkal leher dibagian ventral dan mediumsehingga mengenai arteri carotis. 
Ternak babi yang sudah mati kemudian diangkat kemudian direndam dengan air panas dengan suhu $70-80{ }^{\circ} \mathrm{C}$ didalam wadah yang besar dan dilakukan proses pembersihan yaitu melepaskan bulu dan kulit epidermis, kempat kuku kaki dicabut, kemudian babi diangkat dari ember dan selanjutnya dilakukan proses pembersihan sisa-sisa bulu yang menempel pada tubuh babi sehingga tubuh babi bersih dari kulit epidermis. Babi yang sudah bersih dari bulu selanjutnya dilakukan proses pengeluaran isi perut. Proses pengeluaran jeroan dilakukan dengan keadaaan posisi ternak yang terlentang atau terbaring perut babi menghadap keatas. Pemotongan atau pengirisan bagian perut babi dimulai dari puting susu bawah, setelah itu dilakukan pemotongan atau pengirisan pada perut babi sampai terlihat isi perut babi atau organ dalam pencernaan. Setelah seluru organ dalam atau jeroan keluar, selanjutnya masukan tangan dalam rongga perut sampai rongga dada, kemudian tarik pangkal jantung ke arah belakang sampai isi organ dalam keluar. Organ dalam yang sudah dikeluarkan, kemudian rongga perut babi dibersihkan dengan air sampai tidak ada lagi sisa-sisa darah maupun kotoran lainnya. Setelah sudah bersih dan tidak ada lagi sisasisa darah atau kotoran lainya selanjutnya masuk dalam proses berikutnya yaitu babi ditusuk menggunakan alat pemutar atau penggulingan dimulai dari lubang anus sampai menembus rongga mulut sampai pada ujung pengikat mulut pada pemutar atau penggulingan sesuai dengan ukuran alat pemutar. Selanjutnya kaki dan kepala di ikat menggunakan tali pada alat pemutar, kaki diikat menggunakan tali benang supaya pada proses memutar babi tetap pada posisi pada saat diikat agar dalam proses memutar daging babi dapat masak dengan baik, kemudian diolesi secara merata hingga semua bagian tubuh babi mentah dengan bahan bumbu yang telah diracik. Proses selanjutnya membuat bara api menggunak bahan kayu bakar pada tempat penggulingan yang sudah tersedia. Setelah bara api menyala dengan sepurna, setelah itu babi diangkat dan diletakan disamping bara api. Proses memutar atau penggulingan ini dilakukan oleh dua orang yang satu orang yang memutar alat pengguling dan yang satunya mengatur bara api agar babi mendapatkan panas bara api yang merata, kondisi ini juga disesuaikan dengan banyaknya pesanan, satu orang hanya dapat memutar dua ekor babi dalam satukali memutar. Setelah warna kulit babi yang sudah berwarna cokelat kemerahan tandanya babi guling sudah mulai akan matang. 
Proses memutar masih dilakukan sampai bagian mulut babi mengeluarkan air berwarna putih keruh, pada saat ditusuk dengan besi kecil atau pisau pada bagian leher atau area sela paha dagingnya mulai berwarna putih dan tidak ada warna darah tandanya babi sudah matang. Babi putar yang sudah matang atau masak kemudian diangkat dari tempat pemutar ketempat mengemasan. Selanjutnya babi putar yang telah diangkat tadi dilepaskan dari alat pemutar untuk masuk pada proses pengemasan dan dilakukan oleh dua orang, satu memegang kepala dan yang satu orang lagi menarik alat pemutar dengan berlahan dan kuat. Babi putar yang sudah terlepas dari alat pemutar siap masuk pada proses pengemasan dengan menggunakan plastik dan kardus dan bersamaan dengan sambal (dabu-dabu) yang telah disiapkan.

\section{Pemasaran}

Pemasaran adalah suatu proses sosial dan manejerial dari individu dan kelompok untuk memenuhi setiap kebutuhan dan keinginan melalui penawaran dan pertukaran. Pemasaran adalah upaya menciptakan loyalitas konsumen terhadap produk yang ditawarkan.

Sistim pemasaran yang dilakukan Usaha babi putar Simponi yaitu pemesanan langsung dari konsumen dengan membayar secara tunai ataupun memberi uang muka olahan babi putar sesuai ukuran dan menentukan hari pesanan selain itu memiliki srategi pemasaran yang mengikuti perkembangan teknologi seperti lewat sosial media yaitu Facebook dan Whatsapp sehingga mempermuda setiap konsumen untuk memesan babi putar. Rifai (2017), bahwa kegiatan pemasaran perusahan harus dapat memberikan kepuasan kepada konsumen bila ingin mendapatkan tanggapan yang baik dari konsumen. Pengusaha harus memberikan pelayanan dan kualitas produk yang baik agar dapat memuaskan konsumen, tujuannya untuk memperoleh keuntungan.

\section{Biaya Produksi, Penerimaan dan Keuntungan}

Biaya produksi adalah jumlah pengeluaran atau biaya yang dikeluarkan oleh pemilik usaha untuk proses produksi yang terdiri dari biaya tetap (fixed cost) dan biaya tidak tetap (variable cost). 
Tabel 2. Biaya Total Produksi Pada Usaha Babi Putar Simponi Dalam Satu Tahun

\begin{tabular}{llr}
\hline No & \multicolumn{1}{c}{ Jenis biaya } & Jumlah (Rp/Tahun) \\
\hline $\mathbf{1}$ & Biaya Tetap & \\
& Biaya penyusutan peralatan & 306.417 \\
& Biaya penyusutan bangunan & 2.928 .030 \\
& Biaya pajak & 1.045 .000 \\
$\mathbf{2}$ & Biaya Tidak Tetap & \\
& Biaya ternak babi & 278.900 .000 \\
& Biaya bahan bumbu & 30.074 .000 \\
& Listrik & 840.000 \\
& Upah tenaga kerja & 15.900 .000 \\
& Bahan Bakar & 14.310 .000 \\
& Transportasi & 9.540 .000 \\
\hline $\mathbf{3}$ & Total Biaya Produksi & $\mathbf{3 5 3 . 8 4 3 . 4 4 7}$ \\
\hline
\end{tabular}

Berdasarkan Tabel 2, biaya yang paling besar dikeluarkan oleh pemilik usaha babi putar adalah penyediaan ternak babi sebesar Rp 278.900.000/tahun. Sedangkan pada biaya bahan bumbu pemilik usaha mengeluarkan biaya sebesar 30.074.000/tahun. Pengeluaran pada bahan bakar adalah sebesar Rp. 14.310.000/tahun. Upah tenaga kerja yang dikeluarkan pemilik usaha untuk membayar tenaga kerja sebesar Rp. 15.900.000/tahun. Biaya listrik adalah sebesar Rp. 840.000/tahun, sedangkan untuk biaya trasportasi sebesar Rp. 9.540.000/tahun.

\section{Penerimaan}

Total penerimaan adalah jumlah seluruh penerimaan pengusaha sebagai produsen dari hasil penjualan produk. Berdasarkan pada hasil penelitian pada usaha babi putar Simponi memperoleh penerimaan yaitu sebesar Rp.508.200.000/tahun atau Rp 42.350.000/bulan dari hasil penjualan babi putar sebanyak 318 ekor yang beratnya bervariasi dari $15 \mathrm{~kg}, 20 \mathrm{~kg}, 25 \mathrm{~kg}$ dan $30 \mathrm{~kg}$. Dari hasil penelitian, permintaan konsumen paling banyak adalah pada babi putar yang berukuran $25 \mathrm{~kg}$ dikarenakan tekstur daging yang halus dan lembut. Penelitian ini juga dilakukan oleh Sastrawan et al. (2017) bahwa hasil penerimaan usaha babi guling di Provinsi Bali sebanyak 108 ekor yaitu sebesar Rp. 96.950.000 selama dua bulan atau Rp 48.475.000/bulan. Hal ini menunjukan bahwa penerimaan babi putar di Kota Manado masih kurang dibandingkan dengan penerimaan babi guling di Bali dikarenakan babi guling di Bali merupakan makanan khas sehingga permintaan babi guling di Bali lebih tinggi dan harga babi guling lebih murah. 
Tabel 3. Keuntungan Babi Putar Simponi

\begin{tabular}{lr}
\multicolumn{1}{c}{ Uraian } & Total (Rp/tahun) \\
\hline Total Biaya Produksi & 353.843 .447 \\
Total Penerimaan & 508.200 .000 \\
Keuntungan Usaha & 154.356 .553 \\
\hline
\end{tabular}

\section{Keuntungan}

Berdasarkan Tabel 3, total penerimaan usaha babi putar Simponi sebesar Rp. 508.200.000/tahun. Dikurangi dengan biaya produksi sebesar Rp. 353.843.447/tahun. Sehingga dari hasil penelitian ini menunjukan bahwa keuntungan bersih yang didapat dari pemilik usaha babi putar Simponi sebesar Rp. 154.356.553/tahun.

\section{KESIMPULAN}

Berdasarkan hasil penelitian dapat disimpulkan bahwa usaha babi putar Simponi sudah berpengalaman dalam berusaha dengan teknik pengolahan yang mempunyai ciri khas sendiri sehingga menghasilkan produk babi putar yang banyak diminati.

Total biaya produksi yang dikeluarkan oleh usaha babi putar Simponi dalam satu tahun adalah Rp. 353.843.447 dengan toral penerimaan sebesar Rp. 508.200.000/tahun sehingga memberikan keuntungan usaha sebesar Rp. 154.356.553/tahun.

\section{DAFTAR PUSTAKA}

Agustiyarini, Y., B. Asyik, dan D. Miswar. 2017. Deskripsi sosial ekonomi pemilik usaha warung makan di Kelurahan Kampung Baru Kecamatan Labuhan Ratu Kota Bandar Lampung. Jurnal Fakultas Keguruan dan Ilmu Pendidikan Universitas Lampung 1(1):2-12

Badan Pusat Statistik Sulawesi Utara. 2019. Sulawesi Utara Dalam Angka. Manado.

Badan Pusat Statistik Sulawesi Utara. 2018. Sulawesi Utara Dalam Angka. Manado.

Baron, R. A. 2009. Effectual versus predictive logics in entrepreneurial decision making: differences between experts and novices does experience in starting new ventures change the way entrepreneurs think? Perhaps, but for now, "Caution" is essential. Journal of Business Venturing 24(1):310-315

Ernayati, 2003. Esiklopedia Makanan Tradisional Di Pulau Jawa dan Pulau Madura. Proyek Pelestarian Dan Pengembangan Tradisi dan Kepercayaan. Jakarta.

Hapsari, I. M. 2014 Identifikasi berbagai permasalahan yang di hadapi oleh UKM dan peninjauan kembali regulasi UKM sebagai langkah awal revitalisasi UKM. Journal Permana 5(2):43-47 
Hartono dan D.D. Hartono 2014. Faktorfaktor yang mempengaruhi UMKM di Surakarta. Jurnal Bisnis Dan Manajemen 14(1) : 15-30

Juliandri, Janrizal dan Taryono 2017. Analisis kelayakan usaha makanan tradisional kue bangkit di Kota Pekan Baru. Journal Of Manejemen 4(1):1-13

Kandou, G. D. 2009. Kebiasaan Makan Makanan Etnik Minahasa di Provinsi Sulawesi Utara. Journal Kesehatan Masyarakat. 3(2) :1522.

Pitanatri, P. D. S. 2016. Inovasi dalam kompetisi: usaha kuliner lokal menciptakan keunggulan kompetitif di Ubud. Jurnal Master Pariwisata 3(1):1-27

Rawis, J. E. O., V. V. J. Panelewen, dan A. D. Mirah, 2016. Analisis keuntungan usaha kecil kuiner dalam upaya pengembangan Umkm Di Kota Manado (studi kasus usaha katering Miracle Ranotana Weru. Jurnal EMBA 4(2):106-119

Rifai, M., P. Y. Leksono dan R. Kurniawan. 2017. Pengaruh kualitas pelayanan, harga, dan promosi terhadap kepuasan pelanggan pada rumah makan ayam geprek spesial sambal korek cabang Kediri. Universitas Nusantara PGRI Kediri. Jurnal Sikmi-Economic 1(3):1-13

Sastrawan, N. P. K. P., K. Budaarsa Dan I. G. Mahardika 2017. Proses pembuatan babi guling dan analisis vinansial dengan bahan baku babi Bali (studi kasus pada perusahan babi guling babi Bali milik Made Sunaka). Jurnal Peternakan Tropika 5(2):283-298
Suarna, I. W, N. Suryani, dan A. A. A. S. Trisnadewi. Plasma nutfah babi bali mutiara yang terpendam. Jurnal bumi lestari, 5 (2): 103-108.

Soekartawi, 2006. Analisis Usaha Tani: UI Press, Jakarta. 